\title{
Effects of Lifting COVID-19 Lockdown on Ambient Air Particulate Matter and Associated Health Risk at Uganda Christian University's Main Campus, Mukono
}

\author{
Edward Kibikyo Mukooza ${ }^{1 *}$, Sarah Kizza-Nkambwe ${ }^{2}$ \\ ${ }^{I}$ Department of Public Health, School of Medicine, Uganda Christian University \\ ${ }^{2}$ Quality Assurance, Uganda Christian University \\ *Corresponding Author: mukooza_edward@yahoo.com
}

\begin{abstract}
Introduction: Lockdowns control the spread of SARS-CoV-2 virus and are associated with improved air quality. Uganda imposed a lockdown beginning March $18^{\text {th }}$ and begun easing it on the $2^{\text {nd }}$ of June 2020. This study analysed ambient air PM2.5 at Uganda Christian University's (UCU) main campus during and after the lockdown. Health risk reflected by avoidable premature deaths associated with poorer air quality due to lifting of the lockdown was also estimated.

Methods: Laser particle counter, Purple Air PA-II, measured ambient Air PM2.5 concentration at UCU main campus for the lockdown period of $8^{\text {th }}$ April to $30^{\text {th }}$ June 2020. Excel Toolpak was used for data analysis and the health risk assessed with the World Health Organisation's AirQ+ tool.

Results: The 24-hour ambient mean PM2.5 count was $16.61 \mu \mathrm{g} / \mathrm{m}^{3}$ during the lockdown and it increased to $35.57 \mu \mathrm{g} / \mathrm{m}^{3}$ on lifting of the lockdown. The increased PM2.5 is associated with a higher risk of preventable premature deaths. Vehicles using adjacent roadways were the likely source of ambient air PM2.5 at UCU.

Discussion: Ambient air PM2.5 during the lockdown was moderate on the Air Quality Index and it deteriorated to unhealthy for sensitive people during the lifting of the lockdown which raised the risk of preventable premature deaths. Air quality at UCU main campus could be improved by planting a wide vegetation fence next to the adjacent roads, using cleaner fuel in the University's kitchen, lobbying for paving Bishop Road and placing new buildings away from roads. These would improve health including Covid-19 outcomes.
\end{abstract}

Keywords: COVID-19; Lockdown; Particulate matter; Air quality; Health risk; Uganda Christian University.

\section{Introduction}

The Corona Virus Disease 2019 (COVID2019) is caused by the Severe Acute Respiratory Syndrome Coronavirus 2 (SARS-CoV-2), an emerging viral infection. The disease was first reported to the World Health Organisation's Country office in China on December $31^{\text {st }} 2019$ and declared a pandemic on $11^{\text {th }}$ March, 2020 (WHO, 2020). According to the USA Centre for Disease Control [CDC] (2019), the disease spreads by respiratory droplets from an infected person or by touching fomites contaminated with the virus and then touching the eyes, nose or the mouth. The elderly, men and people with comorbidities are more susceptible to COVID19 (Johns Hopkins, 2020; Jin et al., 2020). Prevention of COVID-19 infection is by improving hand and respiratory hygiene, social distancing and self-isolation when unwell with any respiratory symptoms (WHO, 2020). The symptoms of COVID-19 can be fever or chills, cough, tiredness, difficult breathing, aches and pains, loss of taste, headache, a rash and others. There is currently no cure for COVID-19 disease and the main focus of treatment is supportive and relieving symptoms like pain, cough, dehydration and fatigue. To slowdown the spread of SARS-CoV-2 so that health systems may not be overwhelmed, lockdowns which restrict movement of people, have been imposed by governments (Gave, 2020). Lockdowns, when combined with other preventive measures can suppress the basic viral reproduction number $\mathrm{R}_{0}$, to below one (Ferguson et al., 2020). In addition to slowing the disease 
spread, an unexpected benefit of improved air quality is associated with lockdowns (American Geophysical Union, 2020; Shi \& Brasseur 2020). Air pollution is associated with respiratory health problems, heart disease, lung and other cancers, poor pregnancy outcomes, poor COVID-19 outcomes and lower student grades (WHO, 2019; Wu et al., 2020; Grippo et al., 2018; Zweig \& Ham, 2009). Particulate matter (PM), which has no known threshold below which there is no health risk, is used as proxy indicator for air pollution. Literature shows that a $6 \%$ increase in all-cause mortality is associated with each $10 \mu \mathrm{g} / \mathrm{m}^{3}$ rise in ambient air particulate matter of size $2.5 \mu \mathrm{m}$ [PM2.5] (WHO, 2006; WHO, 2018; Sanyal et al., 2018). This concentration response function describes risk in a defined population and not at individual level (WHO, 2016). Particulate matter sized 2.5 $\mu \mathrm{m}$ originates primarily from combustion sources such as fossil fuel driven automobiles and biomass burning (WHO, 2006). Although there is no evidence for a threshold below which there no health risk, based on available evidence of association between air pollution and health effects, WHO set PM2.5 limits of $10 \mu \mathrm{g} / \mathrm{m} 3$ for annual mean and $25 \mu \mathrm{g} / \mathrm{m}^{3}$ for 24-hour mean to guide efforts to improve air quality in varying contexts (WHO,2006). This study analysed ambient air particulate matter concentration at Uganda Christian University during the lockdown and during the lifting of the lockdown. Health risk, reflected by preventable premature deaths, associated with long term exposure to poorer air quality due to the lifting of lockdown were estimated using the WHO (2018b) AirQ+ and the WHO (2005) limit for annual PM2.5.

\section{Methodology}

The setting; Uganda Christian University's (UCU) main campus is located in Mukono Town Council which is 21 kilometers east of Kampala along the busy Kampala-Jinja highway which connects the land locked Uganda and surrounding countries to the port of Mombasa. The student population at UCU main campus is about 3,000 to 6,000 during any one of three semesters in a year. The university has about 1,000 employees. Most UCU students are undergraduates with over $70 \%$ aged 20-25years and about 22\% aged above 25 years (Mukooza, Kikule and Carabine, 2018). The campus is about one kilometer off the Kampala Jinja Highway but a busy feeder road used as an alternative route by traffic to and from Kampala, Bishop Road, is adjacent to it.

\section{Materials}

A laser particle counter, PurpleAir (PA-II) Sensor was used to collect data for the period April $8^{\text {th }}$ to June $30^{\text {th }} 2020$. The PA-II sensor data correlates highly $(r>0.9)$ with the Standard United States Environmental Protection Agency (EPA) methods (South Coast AQMD, 2015) and it continuously samples data for longitudinal studies when it is connected to stable power supply. The sensor range of $-20 \sim+60{ }^{\circ} \mathrm{C}$ and 0 99\% fits with the Ugandan environment with high humidity most of the year and temperature of $24-33^{\circ} \mathrm{C}$ (Elite Weather Systems NZ, 2020). The PA-II effective range of $0 \sim 500 \mu \mathrm{g} / \mathrm{m}^{3}$ and maximum range of $\geq 1000 \mu \mathrm{g} / \mathrm{m}^{3}$ is appropriate in environments where previous studies in nearby urban areas found concentrations of particulate matter above $100 \mu \mathrm{g} / \mathrm{m}^{3}$ (Elite Weather Systems NZ, 2020; Kirenga et al., 2015; Schwander et al., 2014; US Embassy in Kampala, 2019). Considering that the land area of the university was fitting within the EPA middle scale of representativeness since the campus radius is $\approx 0.5 \mathrm{~km}$, one sensor was considered to be able to collect representative data for the campus (EPA, 2017). The sensor was installed on the Hamu Mukasa Library building which is located at about the center of the Uganda Christian University's main campus. It was mounted on a building located at about the middle of the 64 acre campus, at a height of about 15 feet off the ground and connected to stable power and Wi-Fi. The sensor, when registered on the purple air map, reports downloadable data to the map every two minutes in micrograms per cubic meter for PM1, PM2.5 and PM10.

\section{Data collection and analysis}

The laser particle counter, PA-II, reports PM2.5 mass concentration in $\mu \mathrm{g} / \mathrm{m}^{3}$ on a downloadable excel sheet. The data was analysed with Excel data analysis toolpak. The health risk was calculated using the WHO (2018) AirQ+ software tool for health risk assessment of air pollution. The WHO tool calculates health risk for a defined population like that of UCU and may not be used for 
calculating individual health risk (WHO, 2006; WHO, 2016). The adverse health outcome of interest in this study was premature deaths due to long term exposure to air pollution. The WHO (2005) annual mean air quality limits for PM2.5, the ambient air PM2.5 mean measured by PA-II sensor during and after the lockdown, the Uganda crude death rate of $655.4 / 100,000$ and an estimated annual population of 6000 students and 1000 staff were used in the health risk assessment (WHO,2005; WHO, 2016: World Bank, 2020). The Environmental Health Risk Assessment Model [enHEALTH] (2012) informed the methodology. The main issue being the potential gain in terms premature deaths prevented if the improvement in the quality of air related to COVID-19 lockdown was maintained after the lockdown. The main hazard considered in this study is the ambient air PM2.5 concentration. The main exposure pathways were inhalation and contact with eyes and the skin.

\section{Results}

Figure 1 in the appendix shows the trend of PM2.5 ambient air concentration during the lockdown and during the gradual lifting of the lockdown versus the annual WHO (2005) limit of ambient air PM2.5 concentration which is 10 $\mathrm{ug} / \mathrm{m}^{3}$. Table 1 shows that the 24-hour ambient air mean concentration of PM2.5 increased by about $127 \%$ when the lockdown was lifted and the minimum concentration changed by approximately $483 \%$. The maximum 24 hour mean ambient air concentration of PM 2.5 and the standard deviation did not change much between the lockdown days and during its lifting. The number of days on which the 24 hours mean concentration of ambient PM2.5 exceeded the WHO limit increased from $82 \%$ to $100 \%$ when the lock down was lifted. In table 2, day time and night time mean PM2.5 in $\mathrm{ug} / \mathrm{m}^{3}$ during the lockdown were compared. A paired ttest to compare the day time and night time mean PM2.5 concentration showed that the two means were significantly different with a pvalue of 0.045 . The day time PM2.5 concentration was higher during the lockdown. In table 3, a paired t-test to compare the day time and night time mean PM2.5 concentration during the easing of the lock showed that the two means were significantly different with a pvalue of 0.049 . Additionally, the night time
PM2.5 concentration varied more with a standard deviation of 10.05 compared to 6.94 during day and it was higher during the easing of the lockdown.

\section{Risk assessment during and after the lockdown}

In table 4, the assessment using WHO AirQ+ (2018) and the mean PM2.5 concentration of $15.61 \mu \mathrm{g} / \mathrm{m} 3$ show that in one years, 2 deaths in the UCU community would be avoided annually if the ambient air PM2.5 was kept at the WHO limit of $10 \mathrm{ug} / \mathrm{m}^{3}$. If the population of UCU was scaled up to 100,000 people at PM2.5 of 16.61 $\mathrm{ug} / \mathrm{m}^{3}$, then the number of preventable premature deaths would be approximately 22 . In table 5, the assessment using the mean PM2.5 concentration of $35.57 \mathrm{ug} / \mathrm{m}^{3}$ measured during the lifting of the lock suggests that 7 premature deaths due to long term exposure to PM2.5 in the UCU community were avoidable annually if the concentration of PM2.5 would not exceed the WHO limit of $10 \mu \mathrm{g} / \mathrm{m} 3$. If the population of UCU was scaled up to 100,000 people at PM2.5 of $35.57 \mathrm{ug} / \mathrm{m}^{3}$, then the number of preventable premature deaths would be approximately 94 . As the lifting of the Covid-19 lockdown continued, the concentration of PM2.5 in the ambient air would likely increase towards the levels that have been previously measured in other Ugandan towns. In table 6, it was assumed that what was the upper confidence level during the easing of the lockdown could become the mean when the lifting of the lockdown is complete with all activities at UCU and the surroundings back to normal levels. The assessment using WHO AirQ+ (2018), the WHO (2005) limit of $10 \mu \mathrm{g} / \mathrm{m}^{3}$ and the mean PM2.5 concentration of $53.67 \mathrm{ug} / \mathrm{m}^{3}$ after the complete lifting of the lockdown suggested that 11 premature deaths in the UCU community caused by long term exposure to PM2.5 could be avoided annually if the concentration of PM2.5 would not exceed $10 \mu \mathrm{g} / \mathrm{m} 3$.

\section{Discussion}

Ambient air concentration of PM2.5 during lockdown and during its easing.

The trend of PM2.5 concentration in ambient air at UCU main campus during the period of the lockdown (April- May, 2020) showed daily variations with a 24 hour mean of $15.61 \mathrm{ug} / \mathrm{m}^{3}$. This is below the WHO 24 hour mean limit of 
$25 \mathrm{ug} / \mathrm{m}^{3}$ but it is above the annual limit of 10 $\mathrm{ug} / \mathrm{m}^{3}$ which was used in the calculations of avoidable premature deaths. Comparing the lockdown period and the easing of the lockdown, PM2.5 air pollution was most likely driven by vehicle traffic because this was the major known polluting variable affected by the lockdown in the neighborhood of UCU main campus (WHO, 2005). At the peak of the lockdown, traffic was reduced to mostly cargo vehicles and few essential workers'cars. During the easing of the lockdown, passenger vehicles and private cars were allowed back on the road. In the lockdown period, the day time mean concentrations of PM 2.5 were significantly higher than the night time values with a p-value of 0.045 . The higher day time values during the lockdown may be explained by the higher numbers of cargo tracks during day since the roads were generally free of other traffic. A 24 hour mean of $15.61 \mathrm{ug} / \mathrm{m}^{3}$ on the United States EPA Air Quality Index (AQI) falls in the yellow zone which is said to be associated with moderate level of health concern and where there may be a health risk for some people, particularly those who are unusually sensitive to air pollution. According to WHO (2005), there is little evidence for a threshold below which PM2.5 is not a risk to health and therefore, there is health risk associated with PM2.5 concentration of $15.61 \mathrm{ug} / \mathrm{m}^{3}$ even though it is below the WHO 24 hour mean limit of 25 $\mathrm{ug} / \mathrm{m}^{3}$. When the lockdown begun to be eased on June the $2^{\text {nd }}$, the ambient air concentration of PM2.5 deteriorated to a 24 hour mean of 35.57 $\mathrm{ug} / \mathrm{m}^{3}$ which was above the limit of $25 \mathrm{ug} / \mathrm{m}^{3}$ recommended by WHO (2005). The 24 hour mean during the easing of the lockdown fell within the EPA range of $35.5-5.4 \mathrm{ug} / \mathrm{m}^{3}$ which is orange on the EPA Air Quality Index. This quality of air is unhealthy for sensitive people for whom it may cause negative health effects (AirNow, 2020). During the easing of the lockdown, the entire daily variation of the 24 hour mean was above the WHO (2005) annual cut off level which implied worsening air quality. The day time mean concentration of PM2.5 during the easing of the lockdown was significantly lower than the night time concentration with a p-value of 0.049 . The probable explanation may be the higher numbers of cargo at night when there was fewer other traffic due to the curfew restricting passenger vehicle movement after $7 \mathrm{pm}$. The deteriorating air quality during the easing of the lockdown was likely related to the increasing traffic in the neighborhood of the university since according to Uganda National Environment Management Authority (NEMA), automobile emissions and road dust in urban areas are a major contributor to air pollution in Uganda and WHO asserts that the primary source of PM2.5 is combustion (NEMA, 2019; WHO, 2005). The lockdown was not yet completely lifted since there were still restrictions on motorcycle use, a curfew between the hours of $7.00 \mathrm{pm}$ and $6.30 \mathrm{am}$ and schools and churches were still closed. In addition, there were no students on campus and staffs were still limited to the essential employees and residents meaning that activities on campus were still as limited as they were during the lockdown. The university kitchen, where predominant fuel was wood, was not operational and there were hardly any cars on campus. When the easing is completed and all activities are restored, it is likely that the air quality would deteriorate further. Previous studies conducted in Uganda showed air pollution levels as high as five times the WHO (2005) cut off limits (Kirenga et al., 2015; Schwander et al., 2014; IQAir, 2018 and US Embassy in Kampala, 2019). It could therefore be predicted that the ambient PM2.5 concentration at the UCU main campus would increase towards $100 \mathrm{ug} / \mathrm{m}^{3}$ and beyond if there were no intervention to improve air quality. A hypothetical mean of $53.67 \mathrm{ug} / \mathrm{m}^{3}$ after the lockdown was completely lifted, could lead to 11 avoidable annual deaths in the UCU coomunity or 152 premature deaths per 100,000 population. These premature deaths could be prevented if the air quality attained during the lockdown could be maintained in the long term. These premature deaths could be more if the COVID-19 pandemic continued amidst high ambient air particulate matter count since there is evidence that the outcome of SARS-CoV-2 viral infection is made worse by air pollution (Wu et al., 2020).

\section{Discussion of Risk assessment}

In this study, the outcome of interest was the preventable premature deaths in the UCU community associated with long term exposure to PM2.5. The UCU estimated population of 7000 students and staff is small and therefore the number of avoidable annual premature deaths 
ranging from 2 to 11 depending on the PM2.5 concentration appears small. When the denominator population is scaled up to 100,000 , the number of preventable premature deaths ranges between 21 and 151 depending on the PM2.5 concentration. As the ambient air concentration of PM2.5increased, the number of avoidable deaths also increased as predicted by the concentration response function (WHO, 2005). The easing of the lockdown was not yet complete. There were many activities which when permitted, would lead to higher pollution levels and these included motor cycles which are known to be even more polluting that other motor vehicles (Vasic and Weilenmann, 2006). Students were still at home and the curfew still restricted night time activities including movement of passenger cars. The completion of the easing of the lockdown would increase pollution and a hypothetical higher ambient air PM2.5 concentration of $53.67 \mathrm{ug} / \mathrm{m}^{3}$ may even be an under estimate given that previous studies found higher values in Ugandan urban areas (Kirenga et al., 2015; Schwander et al., 2014; IQAir, 2018 and US Embassy in Kampala, 2019). The ambient air PM2.5 value of 53.67 $\mathrm{ug} / \mathrm{m}^{3}$ would lead to 11 avoidable deaths annually at UCU. When the denominator is scaled up to 100,000 population, the avoidable deaths would be 152 annually if the long term PM2.5could be maintained at or below the WHO (2005) annual mean of $10 \mathrm{ug} / \mathrm{m}^{3}$.

\section{Conclusion}

The COVID-19 Lockdown in Uganda was a natural experiment where the anthropogenic activities known to pollute air, especially automobile traffic, were reduced to a minimum for a period of about two months of April to May 2020. The primary source of ambient air pollution at UCU, were likely to be vehicles plying the adjacent Bishop road and KampalaJinja highway because the lockdown reduced traffic and its easing increased traffic. The lifting of the lockdown was associated with higher ambient air concentration of PM2.5 compared to the lockdown period. Given the documented concentration-response function of $6 \%$ increase in all-cause mortality associated with each 10 $\mu \mathrm{g} / \mathrm{m}^{3}$ rise in ambient air PM2.5, the higher concentration of ambient air PM2.5 was associated with increased risk for preventable all-cause premature deaths in the UCUcommunity.

\section{Recommendations}

Traffic is largely beyond the control of Uganda Christian University. However, to reduce ambient air pollution and improve health, the university may plant and nature a wide evergreen vegetation barrier alongside the adjacent Bishop and Cathedral rise roads to trap dust and other pollutants from the vehicles (Tong et al., 2015; EPA, 2015). The university should use electricity or LPG for cooking and not wood or charcoal which are known sources of particulate matter. The quality of air on campus should be monitored to inform appropriate interventions. The University's leadership should lobby government to pave the Bishop road to reduce dust from it. Resources should be mobilized to ensure that all roads and footpath on campus are paved. Driving cars and motor cycles on campus may be minimized by designating car parking near the main gate. In the long term planning, new classrooms and residential buildings should be placed at least 500 feet away from the busy adjacent roads (EPA, 2015). Such measures are possible and their implementation would improve students' grades and health outcomes including the COVID-19 outcomes. At national and global level, efforts to control the COVID19 pandemic should integrate intentional interventions to reduce air pollution since current evidence suggests that this would improve the COVID-19 treatment outcomes.

\section{Limitations}

The ambient air PM2.5 at Uganda Christian University's main campus at Mukono before the lockdown is not known. Thus it is not possible to compare data before lockdown with data during and after lockdown. However, there is data before lockdown from other towns and it is referenced in discussion.

\section{Acknowledgement}

This work was done with support from management of Uganda Christian University who permitted data to be collected from the campus and provided ethical exemption since there no collection of data from human subjects. 


\section{Further research}

It would be of value to collect data on ambient PM2.5 at UCU after the lockdown is completely lifted and after the students are back on campus to measure the full extent of air pollution and avoidable deaths at UCU.

\section{References}

[1]. AirNow. 2020. AQI Basics. From: https://www.airnow.gov/aqi/aqibasics/\#: :text=Think\%20of\%20the\%20AQI\%20as,3 00\%20represents\%20hazardous\%20air\%20quality.

Accessed on the $6^{\text {th }}$ of June 2020.

[2]. American Geophysical Union. (2020, May 11). COVID-19 lockdowns significantly impacting global air quality. Science Daily. Retrieved June 29, 2020 from:

www.sciencedaily.com/releases/2020/05/200511124 444.html

[3]. CDC.2019. what you should know about COVID-19 to protect yourself and others. From: https://www.cdc.gov/coronavirus/2019-

ncov/downloads/2019-ncov-factsheet.pdf accessed on the 27th June 2020

[4]. Elite Weather Systems NZ.2020. PURPLEAIR AIR QUALITY SENSOR PA-II-SD. From: https://www.elite-weather-systems-

nz.com/products/purpleair-air-quality-sensor-pa-ii (accessed on the 13th Feb.2020).

[5]. EPA. 2017. Quality Assurance Handbook for Air Pollution Measurement Systems Volume IIAmbient Air Quality Monitoring Program. https://nepis.epa.gov/Exe/ZyPDF.cgi/P100R631.PDF ?Dockey=P100R631.PDF accessed on the 12th July 2020.

[6]. EnHEALTH. 2012. Environmental Health Risk Assessment. Guidelines for assessing human health risks from environmental hazards. From: www.health.gov.au/internet/main/publishing.nsf/cont ent/A12B57E41EC9F326CA257BF0001F9E7D/\$Fil e/Environmental-health-Risk-Assessment.pdf Accessed July 6th 2020.

[7]. EPA. 2015. Best Practices for Reducing NearRoad Pollution Exposure at Schools. From: https://www.epa.gov/sites/production/files/2015-

10/documents/ochp_2015_near_road_pollution_book let_v16_508.pdf

[8]. Gavi.2020. WHY IS CORONAVIRUS LOCKDOWN NECESSARY? From: https://www.gavi.org/vaccineswork/whycoronavirus-lockdown-necessary accessed on June 27th, 2020.
[9]. Grippo, A., Zhang, J., Chu, Li., Guo, Y., Qiao, L., Zhang, J., Myneni, A. A., \& Mu, L. 2018. Air pollution exposure during pregnancy and spontaneous abortion and stillbirth, Reviews on Environmental Health, 33(3), 247-264.doi: https://doi.org/10.1515/reveh-2017-0033

[10]. Jin. J., Bai. P., He.W., Wu.F., Liu.X., Han.D., Liu $S$ and Yang.J. 2020. Gender Differences in Patients With COVID-19: Focus on Severity and Mortality. From: https://www.frontiersin.org/articles/10.3389/fpubh.20 $20.00152 /$ full accessed on $27^{\text {th }}$ June 2020.

[11]. Johns Hopkins. 2020. Coronavirus and COVID19: Who is at higher risk? From: https://www.hopkinsmedicine.org/health/conditionsand-diseases/coronavirus/coronavirus-and-covid19who-is-at-higher-risk accessed on $27^{\text {th }}$ June 2020

[12]. Knoema. 2020. Mortality. From: https://knoema.com/atlas/Uganda/topics/Demographi cs/Mortality/Crude-death-rate accessed on 3rd July 2020.

[13]. Kirenga, B. J., Meng, Q., van Gemert, F., Aanyu-Tukamuhebwa, H., Chavannes, N., Katamba, A., Mohsenin, V. (2015). The State of Ambient Air Quality in Two Ugandan Cities: A Pilot CrossSectional Spatial Assessment. International Journal of Environmental Research and Public Health, 12(7), 8075-8091. https://doi.org/10.3390/ijerph120708075

[14]. Mukooza EK, Kikule E and Carabine D. 2018. Students' Health Seeking Behaviour and its Rationale at Uganda Christian University. Texila International Journal of Public Health Volume 6, Issue 3, Sep 2018 [15]. NEMA. (2019). WORLD ENVIRONMENT DAY. 5TH JUNE 2019 CELEBRATED.

Theme: "Fight Air Pollution to Protect Human Health and Environment"

https://nema.go.ug/sites/all/themes/nema/docs/June\% 202019_NEMA\%20Newsletter\%20(1).pdf (Accessed on the 4th June 2020).

[16]. Sanyal, S.; Rochereau, T.; Maesano, C.N.; Com-Ruelle, L.; Annesi-Maesano, I. Long-Term Effect of Outdoor Air Pollution on Mortality and Morbidity: A 12-Year Follow-Up Study for Metropolitan France. Int. J. Environ. Res. Public Health 2018, 15, 2487.

[17]. Schwander, S., Okello, C., Freers, J., Chow, J.C., Watson, J.G., Corry, M., \& Meng, Q. (2014). Ambient Particulate Matter Air Pollution in Mpererwe District, Kampala, Uganda: A Pilot Study. Journal of environmental and public health.

[18]. Shi, X., \& Brasseur, G. P. (2020). The Response in Air Quality to the Reduction of Chinese Economic Activities during the COVID-19 Outbreak. 
Geophysical Research Letters, e2020GL088070. https://doi.org/10.1029/2020GL088070.

[19]. South Coast AQMD. 2015. PurpleAir PA-II. From:

http://www.aqmd.gov/aq-spec/product/purpleair-pa-ii accessed on the 13th May 2020.

[20]. UCU.2020. About us. From: https://ucu.ac.ug/about (accessed on the 6th of July, 2020).

[21]. U.S. Embassy in Uganda. (2019). Air Quality Monitoring at U.S. Embassy Kampala. Form: https://ug.usembassy.gov/embassy/kampala/airquality-monitoring-at-u-s-embassy-kampala/ (accessed on the 8th Dec. 2019).

[22]. Vasic A and Weilenmann M. Comparison of Real-World Emissions from Two-Wheelers and Passenger Cars. Environ. Sci. Technol., 2006, 40, (1), pp 149-154.

[23]. WHO. 2005. Air Quality Guidelines Global Update 2005.2 From: https://apps.who.int/iris/bitstream/handle/10665/1078 23/9289021926_eng.pdf?sequence $=2 \&$ isAllowed $=y$ accessed on the 12th May 2020

[24]. WHO.2006. Health risks of particulate matter from long-range transboundary air pollution. From: https://www.euro.who.int/_data/assets/pdf_file/0006 178657/E88189.pdf accessed on 9th July 2020

[25]. WHO. 2016. Health risk assessment of air pollution - general principles. Copenhagen: WHO Regional Office for Europe; 2016. From: https://www.euro.who.int/_data/assets/pdf_file/0006 /298482/Health-risk-assessment-air-pollution-

General-principles-en.pdf.

[26]. WHO. 2018. Ambient Air Pollution (outdoor). Key Facts. From: https://www.who.int/news- room/fact-sheets/detail/ambient-(outdoor)-airquality-and-health (accessed on 6th June. 2020).

[27]. WHO. 2018b. AirQ+: software tool for health risk assessment of air pollution. From: https://www.euro.who.int/en/healthtopics/environment-and-health/airquality/activities/airq-software-tool-for-health-riskassessment-of-air-pollution (accessed on May 20th, 2020).

[28]. WHO. 2029. Health consequences of air pollution on populations. From: https://www.who.int/news- room/detail/15-11-2019what-are-health-consequences-of-air-pollution-onpopulations accessed on 30th June 2020.

[29]. WHO.2020. Rolling updates on coronavirus disease (COVID-19). From: https://www.who.int/emergencies/diseases/novelcoronavirus-2019/events-as-they-happen accessed on June 27th, 2020.

[30]. World Bank. 2020. World Development Indicators.

[31]. Wu.X, Nethery RC, Sabath.BM, Braun.D, and Dominici F. 2020. Exposure to air pollution and COVID-19 mortality in the United States: A nationwide cross-sectional study. From: https://www.medrxiv.org/content/10.1101/2020.04.0 $5.20054502 \mathrm{v} 2$.

[32]. Zweig, J.S., \& Ham, J.C. 2009. Air Pollution and Academic Performance: Evidence from California Schools. From: https://pdfs.semanticscholar.org/d74e/327b9d8890d3 93b13d33e7ef851f294e2fdb.pdf accessed on the 30th of June 2020. 
Figure and tables

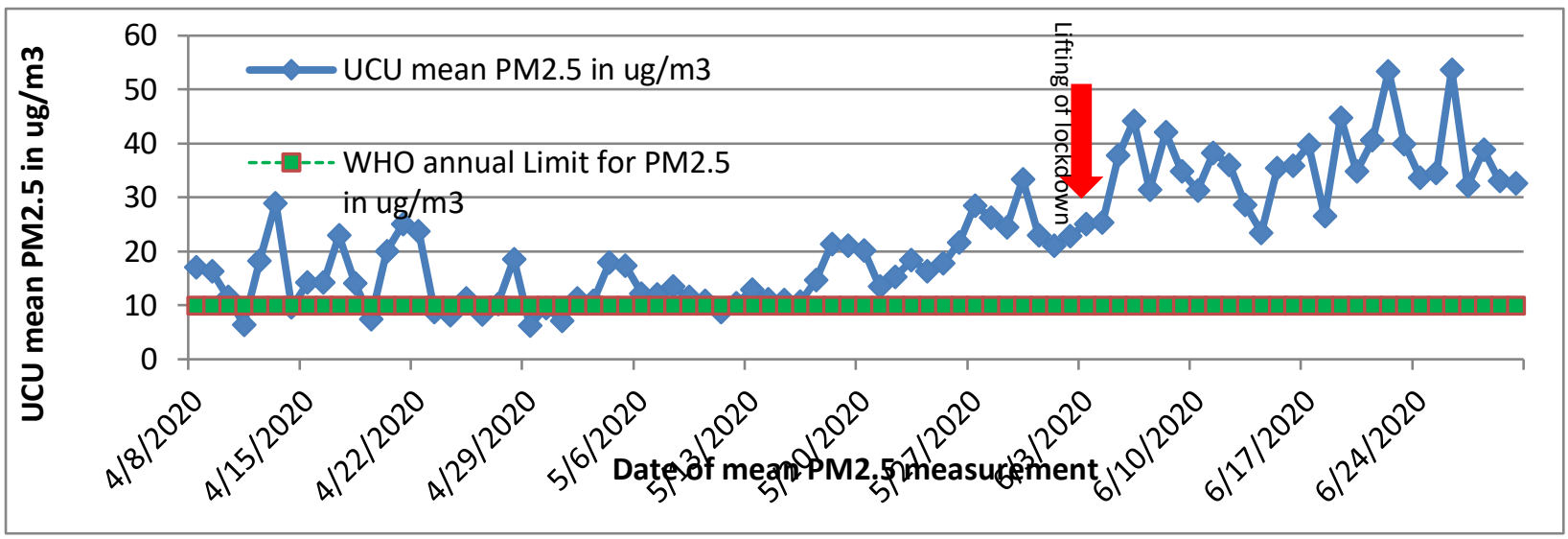

Figure 1. Trend of 24 hour mean ambient air concentration of PM2.5 during and after lifting of COVID- 19 Lockdown compared to WHO (2005) limit of $10 \mathrm{ug} / \mathrm{m}^{3} \mathrm{n}=84$ days

Table 1. Descriptive statistics of PM2.5 in ug/ $\mathrm{m}^{3}$ during and after COVID-19 Lockdown

\begin{tabular}{|l|l|l|l|l|l|}
\hline $\begin{array}{l}\text { Statistic } \\
\text { Period }\end{array}$ & Mean & Minimum & Maximum & $\begin{array}{l}\text { Standard } \\
\text { Deviation }\end{array}$ & $\begin{array}{l}\text { \% of days exceeding } \\
\text { WHO limit of 10 ug/m }\end{array}$ \\
\hline $\begin{array}{l}\text { Lockdown } \\
\text { period }\end{array}$ & 15.61 & 6.22 & 33.36 & 6.27 & 82 \\
\hline $\begin{array}{l}\text { During } \\
\text { lifting of } \\
\text { lockdown }\end{array}$ & 35.57 & 26.29 & 53.63 & 7.43 & 100 \\
\hline $\begin{array}{l}\text { Percentage } \\
\text { change }\end{array}$ & 127.87 & 483.44 & 60.76 & 18.5 & \\
\hline
\end{tabular}

Table 2. Comparing day time and night time mean PM2.5 in ug/m3 during the lockdown $\mathrm{n}=55$ days

\begin{tabular}{|l|l|l|l|l|l|}
\hline $\begin{array}{l}\text { Statistic } \\
\text { Period }\end{array}$ & Mean & Minimum & Maximum & $\begin{array}{l}\text { Standard } \\
\text { Deviation }\end{array}$ & $\begin{array}{l}\text { \% of days exceeding } \\
\text { WHO limit 10 ug/m }\end{array}$ \\
\hline $\begin{array}{l}\text { Lockdown - } \\
\text { Day time }\end{array}$ & 16.63 & 3.72 & 38.21 & 7.17 & $84 \%$ \\
\hline $\begin{array}{l}\text { Lockdown- } \\
\text { Night time }\end{array}$ & 14.51 & 3.69 & 37.93 & 7.51 & $73 \%$ \\
\hline
\end{tabular}

Table 3. Comparing day time and night time mean PM2.5 in ug/m3 during the easing of the lockdown $n=29$ days

\begin{tabular}{|l|l|l|l|l|l|}
\hline $\begin{array}{l}\text { Statistic } \\
\text { Period }\end{array}$ & Mean & Minimum & Maximum & $\begin{array}{l}\text { Standard } \\
\text { Deviation }\end{array}$ & $\begin{array}{l}\text { \% of days exceeding } \\
\text { WHO limit10 ug/m }\end{array}$ \\
\hline $\begin{array}{l}\text { Lockdown } \\
\text { easing - Day } \\
\text { time }\end{array}$ & 32.88 & 15.54 & 48.57 & 6.94 & $100 \%$ \\
\hline $\begin{array}{l}\text { Lockdown } \\
\text { easing -Night } \\
\text { time }\end{array}$ & 36.82 & 15.67 & 66.86 & 10.05 & $100 \%$ \\
\hline
\end{tabular}


Table 4. AirQ+ results for overall mortality attributable to long-term exposure to PM2.5 Ambient air pollution when the mean is $15.61 \mathrm{ug} / \mathrm{m} 3$ during lockdown and WHO limit is $10 \mathrm{ug} / \mathrm{m} 3$

\begin{tabular}{|l|l|l|l|}
\hline Risk & Central & Lower & Upper \\
\hline Estimated Attributable Proportion & $3.32 \%$ & $2.18 \%$ & $4.37 \%$ \\
\hline Estimated Number of Attributable Cases & 2 & 1 & 2 \\
\hline $\begin{array}{l}\text { Estimated Number of Attributable Cases per } \\
100,000 \text { population at risk }\end{array}$ & 21.75 & 15.26 & 28.67 \\
\hline
\end{tabular}

Table 5. AirQ+ results for overall mortality attributable to long-term exposure to PM2.5 Ambient air pollution when the mean is $35.57 \mathrm{ug} / \mathrm{m} 3$ on lifting the lockdown and WHO limit is $10 \mathrm{ug} / \mathrm{m} 3$

\begin{tabular}{|l|l|l|l|}
\hline Risk & Central & Lower & Upper \\
\hline Estimated Attributable Proportion & $14.26 \%$ & $9.54 \%$ & $18.44 \%$ \\
\hline Estimated Number of Attributable Cases & 7 & 4 & 8 \\
\hline $\begin{array}{l}\text { Estimated Number of Attributable Cases per } \\
100,000 \text { population at risk }\end{array}$ & 93.44 & 62.54 & 120.88 \\
\hline
\end{tabular}

Table 6. AirQ+ results for overall mortality attributable to long-term exposure to PM2.5 Ambient air pollution with a hypothetical mean of $53.67 \mathrm{ug} / \mathrm{m} 3$ after the lockdown and WHO limit is $10 \mathrm{ug} / \mathrm{m} 3$

\begin{tabular}{|l|l|l|l|}
\hline Risk & Central & Lower & Upper \\
\hline Estimated Attributable Proportion & $23.1 \%$ & $15.74 \%$ & $29.4 \%$ \\
\hline Estimated Number of Attributable Cases & 11 & 7 & 13 \\
\hline $\begin{array}{l}\text { Estimated Number of Attributable Cases } \\
\text { per 100,000 population at risk }\end{array}$ & 151.41 & 103.17 & 192.72 \\
\hline
\end{tabular}

